\title{
維持透析患者における唾液 $\mathrm{Na} / \mathrm{K}$ 比
}

\author{
熊谷裕通古谷隆一菱田明金子栄蔵 \\ 丸山行孝* 坂尾正** \\ 浜松医科大学第 1 内科 丸山病院* 浜名クリニック**
}

key words : salivary $\mathrm{Na} / \mathrm{K}$, aldosterone, hyperkalemia, hemodialysis, fludrocortisone

〈要旨〉

維持透析患者において, 唾液 $\mathrm{Na} / \mathrm{K}$ 比が腎外 $\mathrm{K}$ 調節の指標として有用か否か調べる目的で, 無尿の血液透析患者 24 名につき 3 か月おきに 3 回，透析開始直前に喠液 $\mathrm{Na}, \mathrm{K}$ ，血清 $\mathrm{K}$ 值，唾液および血墏アルドステロンを測定した。維 持透析患者の唾液 $\mathrm{Na}, \mathrm{K}$ 濃度はとれぞれ $21.3 \pm 2.2,30.2 \pm 3.2 \mathrm{mEq} / l$ で, 健常人の唾液 $\mathrm{Na}, \mathrm{K}$ 濃度, $11.5 \pm 6.4$ $(p<0.05) 22.5 \pm 1.7(p<0.05) \mathrm{mEq} / l$ に比し有意に高值であった。維持透析患者で, 唾液 $\mathrm{K}$ 濃度と血清 $\mathrm{K}$ 值との間 には相関がみられなかったが, 唾液 $\mathrm{Na} / \mathrm{K}$ 比と血清 $\mathrm{K}$ 值との間には有意な負の相関が認められた $(r=-0.43, p<$ 0.01)。維持透析患者の唾液アルドステロン濃度は $23.8 \pm 9.0 \mathrm{ng} / \mathrm{d} l$ と高值を示し, 血漿アルドステロン值 $11 \mathrm{ng} / \mathrm{d} l$ 以上の症例で血漿アルドステロン值と有意な正の相関を示した $(r=0.78, p<0.01)$ 。また，唾液アルドステロン濃 度と唾液 $\mathrm{Na} / \mathrm{K}$ 比とは有意な負の相関を示した $(r=-0.47, p<0.01)$. Fludrocortisone 投与により, 血清 $K$ 值の 有意な低下とともに，唾液 $\mathrm{Na} / \mathrm{K}$ 比は有意に低下し，弚の低下は投与量に依存する傾向がみられた，以上の結果は, 1) 維持透析患者の唾液 $\mathrm{Na} / \mathrm{K}$ 比が, 血清 $\mathrm{K}$ 值の上昇に伴って低下すること， 2 ）炎の機序の少なくとも一部はアル ドステロンを介することを示唆している.したがって，唾液 $\mathrm{Na} / \mathrm{K}$ 比は腎外 $\mathrm{K}$ 調節の指標として有用であると考えら れる。

\section{Salivary $\mathrm{Na} / \mathrm{K}$ ratio in hemodialyzed patients}

Hiromichi Kumagai, Ryuichi Furuya, Akira Hishida, Eizo Kaneko, Yukitaka Maruyama*, Tadashi Sakao** First Department of Medicine, Hamamatsu University School of Medicine ; Maruyama Hospital* ; Hamana Clinic**

Studies were performed to examine whether salivary $\mathrm{Na} / \mathrm{K}$ ratio is a useful indicator of extrarenal potassium adaptation. Concentrations of salivary $\mathrm{Na}, \mathrm{K}$ and aldosterone, serum $\mathrm{Na}$ and $\mathrm{K}$, and plasma aldosterone were measured three times in 24 hemodialyzed patients and 10 healthy controls. Samples were taken just before starting hemodialysis. Salivary $\mathrm{Na}$ and $\mathrm{K}$ concentrations were significantly higher in the hemodialyzed patients $(21.3 \pm 2.2$ and $30.2 \pm 3.2 \mathrm{mEq} / l)$ than in the healthy controls $(11.5 \pm 6.4, \mathrm{p}<0.05$, and $22.5 \pm 1.7, \mathrm{p}<0.05$ $\mathrm{mEq} / l)$. Salivary $\mathrm{Na} / \mathrm{K}$ ratio correlated significantly with serum $\mathrm{K}$ concentration $(r=-0.43, p<0.01)$. In contrast, there was no correlation between salivary $K$ and serum $K$ concentrations. Salivary aldosterone concentration was $23.8 \pm 9.0 \mathrm{ng} / \mathrm{d} l$ in the hemodialyzed patients. A significant positive correlation was found between salivary and plasma aldosterone concentrations in patients with plasma aldosterone levels above $11 \mathrm{ng} / \mathrm{d} l(r=0.78, p<0.01)$. Further, there was a significant negative correlation between salivary aldosterone concentration and salivary $\mathrm{Na} /$ $\mathrm{K}$ ratio $(r=-0.47, \mathrm{p}<0.01)$. Fludrocortisone administration decreased serum $\mathrm{K}$ concomitant with salivary $\mathrm{Na} / \mathrm{K}$ ratio in a dose-dependent manner. These results suggest that salivary $\mathrm{Na} / \mathrm{K}$ ratio decreased in response to an increase in serum $\mathrm{K}$, and that the change in salivary $\mathrm{Na} / \mathrm{K}$ ratio might be mediated, at least in part, by aldosterone.

熊谷 裕通 浜松医科大学第 1 内科 $\quad$ 于 431-31 浜松市半田町 $3600(053-435-2756)$

〔受付: 平成 4 年 2 月 25 日, 受理: 平成 4 年 7 月 8 日〕 


\section{緒言}

透析技術が進歩した今日に抢いても，高カリウム $(\mathrm{K})$ 血症を含む智死は透析患者の全死亡の $3.2 \%$ を占める ことが報告されており ${ }^{1)}$ ，高 $\mathrm{K}$ 血症の対策は重要な課題 である。慢性腎不全の患者では，尿中K排泄の減少に伴 い，代償性に便中への K排泄が増加することが知られて おり, Hayes $ら^{2)}$ は，便中へのK排泄は正常人の約 3 倍 に達すると報告している。この便中への K排泄作用は主 に，大腸に抢ける $\mathrm{K}$ 分泌の六進による ${ }^{3}$ が，その少なくと も一部は，アルドステロンを介するといわれている゙4.ア ルドステロンは，副腎皮質刺激ホルモン $(\mathrm{ACTH})$ や renin による刺激のほか $\mathrm{K}$ の上昇によっても刺激さ $れ^{5}$ ，無尿の透析患者で血清 $\mathrm{K}$ 值が上昇した場合には，ア ルドステロン分泌がえ進し便中の $\mathrm{K}$ 排泄が増加すると考 えられる，このため, 維持透析患者の K代謝の詳細を調 ベるためには，血清 $\mathrm{K}$ 值の上昇に対するアルドステロン の反応性や，便中 K排泄の増加を調べることが重要であ る。しかし，便中のKを測定することは困難であり実際 的でない，そこで今回我々は，唾液が腎外 K調節の指標 として使用し得るか検討する目的で, 唾液中の $\mathrm{Na}, \mathrm{K}$ を 測定し，血清 $\mathrm{K}$ 值，唾液および血漿アルドステロンとの 関連，さらには，ミネラルコルチコイド投与による唾液 $\mathrm{Na} / \mathrm{K}$ 比の変化を測定した。

\section{対象ならびに方法}

対象として維持透析施行中の患者 24 名(男 9 名, 女 15 名)を用いた。年齢は 43 歳加ら 79 歳, 平均 $59.4 \pm 1.9$ 歳 で, 透析歴は 3 年から 16 年, 平均 $9.5 \pm 1.0$ 年であった。 また，対照群として健常人 11 名(男 9 名，女 2 名，平均 年齢 31.1 1.1 歳）を用いた。透析患者の原疾患は，慢 性系球体腎炎 19 名, 糖尿病性腎症 3 名, 囊胞腎 1 名, SLE 1名であった。 1 日尿量は 1 名を除いて $200 \mathrm{~m} l$ 以下で あった。すべての患者で血液透析が行われており，膜面 積 $0.8 \mathrm{~m}^{2}$ から $2.4 \mathrm{~m}^{2}$ の透析器を用いて週 3 回, 1 回 4 〜 5 時間の透析が行われた。これらの患者への食事指導 としては，食塩制限，K制限が行われていたが，今回の 検討に当たって特に摄取量の調查㹥行わなかった。中二 日の透析間の体重増加は $0.6 \mathrm{~kg}$ から $5.1 \mathrm{~kg}$, 平均 $2.4 \pm$ $0.2 \mathrm{~kg}$ であった。投薬内容は特に変更されず，アンギオ テンシン転換酵素阻害薬， $\beta$ ブロッカーなど $\mathrm{K}$ 代謝に影 響を与える薬剤を投与されている者は対象から除外し た。唾液は 3 加月扔きに 3 回，食事，喫煙直後を避け， 透析前に精製水にて目空内を洗浄したのち $1 \sim 5 \mathrm{~m} l$ 採取

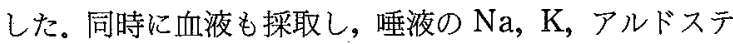
ロン濃度，血清 $\mathrm{K}$ 值，血漿アルドステロン濃度を測定し た。この 3 回の結果は平均值を求めず別個に扱った。

また，高K血症を呈した患者 16 名に対し，fludrocor- tisone acetate (Florinef) を 0.05, 0.10, $0.15,0.20 \mathrm{mg} /$ 日の投与量で 4 週間ずつ経時的に漸増し，唾液 $\mathrm{Na}, \mathrm{K}$ 比，血清 $\mathrm{K}$ 值の変化を調べた。

$\mathrm{Na}, \mathrm{K}$ は炎光光度計で,アルドステロン濃度は CoatA-Count Aldosterone キット（DPC，東京）を用いて測 定した.アルドステロン濃度の測定限界は $2 \mathrm{ng} / \mathrm{d} l$ で, それ以下のものは統計解析から除外した。

結果は，平均值士標準誤差で表し，平均値の差の検定 は Student's $\mathrm{t}$ test を用いた。

\section{結果}

健常人における唾液 $\mathrm{Na}, \mathrm{K}$ 濃度はそれぞれ $11.5 \pm 6.4$ $22.5 \pm 1.7 \mathrm{mEq} / l$ であり，同時に測定した血清 $\mathrm{Na}, \mathrm{K}$ 濃 度はそれぞれ $140.8 \pm 0.4,4.2 \pm 0.1 \mathrm{mEq} / l$ であった。維 持透析患者に扔ける唾液 $\mathrm{Na}, \mathrm{K}$ 濃度はそれぞれ $21.3 \pm$ $2.2,30.2 \pm 3.2 \mathrm{mEq} / l$, ，その際の血清 $\mathrm{Na}, \mathrm{K}$ 濃度はそれ ぞれ $138.0 \pm 0.6,5.14 \pm 0.1 \mathrm{mEq} /$ てであり, 維持透析患者 の唾液 $\mathrm{Na}$ 濃度 $(\mathrm{p}<0.01)$, 唾液 $\mathrm{K}$ 濃度 $(\mathrm{p}<0.05)$ ， 血清 $\mathrm{K}$ 值（ $\mathrm{p}<0.01 ）$ は健常人に比し有意に高值であっ た.

維持透析患者において, 唾液 $\mathrm{K}$ 濃度と血清 $\mathrm{K}$ 值との間 には有意な相関はなかった $(r=0.13, N S)$ が, 唾液 $\mathrm{Na}$ / $\mathrm{K}$ 比は，血清 $\mathrm{K}$ 值と有意な負の相関を示した $(\mathrm{r}=$ $-0.43, \mathrm{p}<0.01$, 図 1$)$.

維持透析患者における唾液アルドステロン濃度は 2 $\mathrm{ng} / \mathrm{d} l$ 以下から最高 $300 \mathrm{ng} / \mathrm{d} l$ と広く分布し, 平均 $23.8 \pm$ $9.0 \mathrm{ng} / \mathrm{d} l$ と高值を示した。唾液アルドステロン濃度は, 血漿アルドステロン值 $11 \mathrm{ng} / \mathrm{d} l$ 以上の患者で血漿アル ドステロン值と有意な正の相関を示した $(\mathrm{r}=0.78, \mathrm{p}<$ 0.01, 図 2)。また，唾液アルドステロン濃度と唾液 $\mathrm{Na} /$ $\mathrm{K}$ 比とは，有意な負の相関を示した（ $\mathrm{r}=-0.47, \mathrm{p}<$ 0.01, 図 3 ). しかし, 血清 $\mathrm{K}$ 值と唾液アルドステロンと の間には相関がみられなかった。

Fludrocortisone acetate 投与により，血清 $\mathrm{K}$ 值は有意 な低下を示した。同時に，唾液 $\mathrm{Na} / \mathrm{K}$ 比も有意に低下し たが，その低下は投与量に依存する傾向がみられた（図 4).

\section{考察}

尿中 K排泄が障害されている透析患者では，腎外の K 調節機序が血清 $\mathrm{K}$ 調節の重要な役割を担っている ${ }^{5)}$ 。腎 外 $\mathrm{K}$ 調節機構では，細胞内外の K分布の調節とともに消 化管，なかでも大腸での K分泌機構が重要であると考六 られている ${ }^{3)}$ また，大腸でのK分泌調節にアルドステロ ンが重要な役割を果たしていることが知られている4).

唾液は, 唾液腺腺房細胞で等張性の原唾液として生成 されるが，原唾液の $\mathrm{Na} ， \mathrm{~K}$ 濃度は血清 $\mathrm{Na}, \mathrm{K}$ 濃度と ほぼ同じであるとされている。原唾液は介在部導管を通 


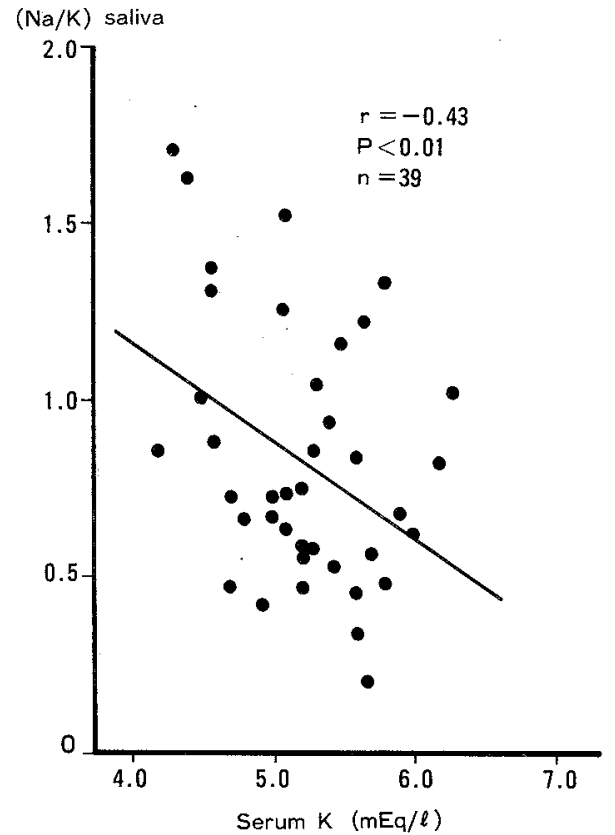

図 1 維持透析患者に拈ける血清 $\mathrm{K}$ 值と唾液 $\mathrm{Na} / \mathrm{K}$ 比の相関

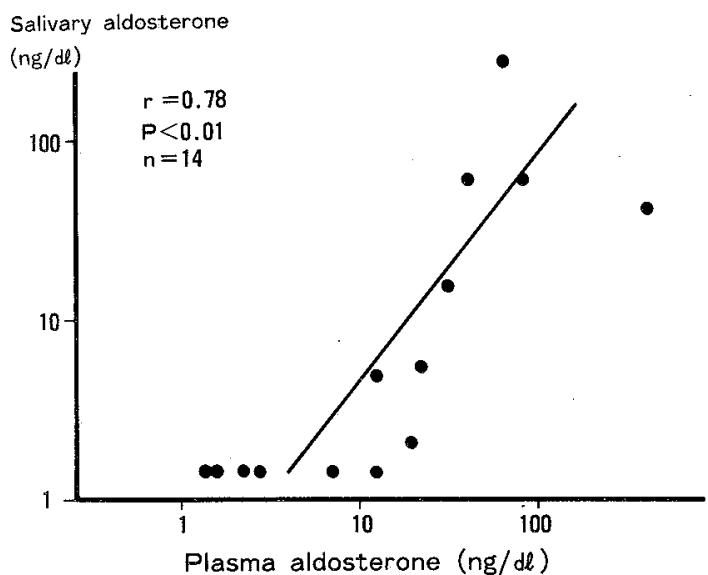

図 2 維持透析患者に拉ける血墏アルドステロン 濃度と唾液アルドステロン濃度

じて線状部導管に入り，そこで $\mathrm{Na}$ の再吸収とKの分泌 が行われるが，線状部導管の基底側の細胞膜には $\mathrm{Na}$ ， K-ATPase が存在しており $\mathrm{Na}$ 再吸収とK分泌に関わっ ていると考えられている6 . 原発性アルドステロン症の 患者では唾液 $\mathrm{Na} / \mathrm{K}$ 比が 0.6 以下と著しく低下してい ることが報告されており7，アルドステロンは $\mathrm{Na}, \mathrm{K}-$ ATPase を刺激して，唾液 $\mathrm{Na} / \mathrm{K}$ 比を低下させる可能 性がある。

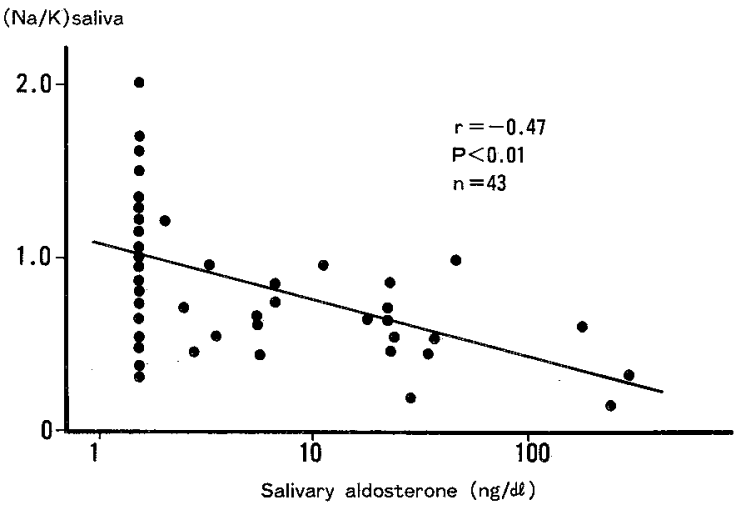

図 3 維持透析患者における唾液アルドステロン 濃度と唾液 $\mathrm{Na} / \mathrm{K}$ 比
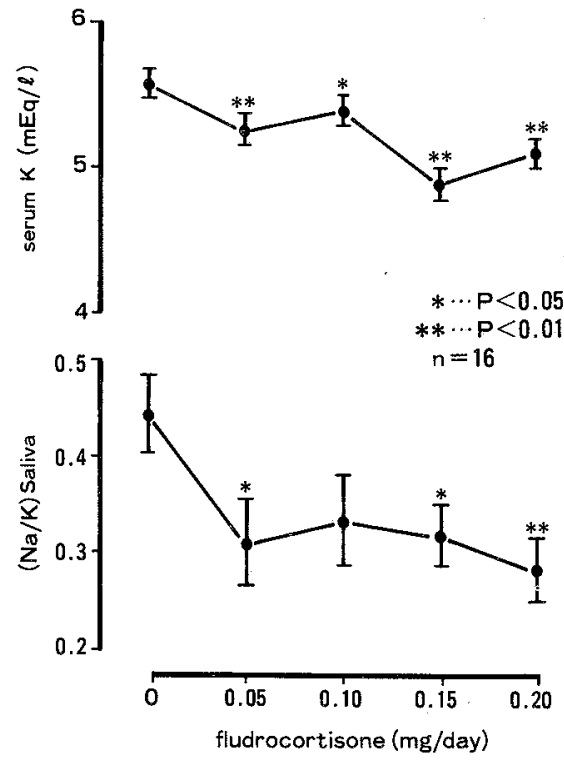

図 4 維持透析患者に打 ける fludrocortisone acetate 投与の血清 $\mathrm{K}$ 值と唾液 $\mathrm{Na} / \mathrm{K}$ 比に 及媇寸効果

今回の検討では，維持透析患者の唾液 $\mathrm{K}$ 濃度は平均で 健常人の 136\%と有意な高値を示し，この結果は，Shasha $ら^{8)}$ と一致した。Burgen は，イヌを用いた検討で, 唾液 $\mathrm{K}$ 值は血清 $\mathrm{K}$ 值と有意な正相関を示し，唾液 $\mathrm{K}$ 值は 血清 $\mathrm{K}$ 值を反映することを報告し ${ }^{9)}$ ，またShasha らも維 持透析患者で同様の結果を示しているが，我々の検討で は唾液 $\mathrm{K}$ 值と血清 $\mathrm{K}$ 值との間には直接の相関がみられな かった。これらの結果の違いの理由は，両者とも唾液 $\mathrm{K}$ 濃度のみ測定し, 唾液の流出量を考慮に入れていないこ とがその可能性の一つと考えられる。唾液 $\mathrm{K}$ 值と唾液量 との関係について，唾液 $\mathrm{K}$ 濃度が，唾液量によって変化

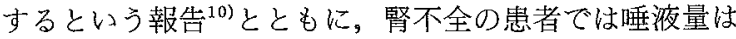


体液量の影響を受け，それにより唾液 $\mathrm{Na} ， \mathrm{~K}$ 濃度も変

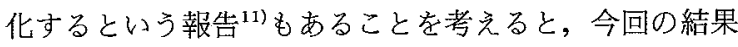
とShasha，Burgen らの報告との違いは，こうした体液 量，唾液量の差を反映した可能性がある。

唾液の電解質組成と血清 $\mathrm{K}$ 值との関係をみると，唾液 $\mathrm{Na} / \mathrm{K}$ 比は血清 $\mathrm{K}$ 值と有意な負の相関を示した。また， 唾液 $\mathrm{Na} / \mathrm{K}$ 比と喠液アルドステロン濃度との関係を調 ベると，両者の間にも負の相関がみられ，唾液アルドス

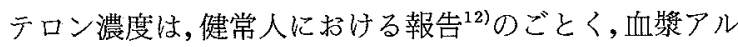
ドステロン濃度と，血漿アルドステロン $11 \mathrm{ng} / \mathrm{d} l$ 以上の 症例で良い相関を示した。さらにアルドステロンと唾液 中の $\mathrm{K}$ と関係をみる目的で，ミネラルコルチコイドで ある fludrocortisone を投与して血清 $\mathrm{K}$ 值，唾液 $\mathrm{Na} / \mathrm{K}$ 比の変化を検討したところ，血清 $\mathrm{K}$ 值の有意な低下がみ られたが，この際，唾液中の $\mathrm{Na} / \mathrm{K}$ 比の低下を伴った。 これらの結果は, 維持透析施行中の患者では, 血清 $\mathrm{K}$ 值 の上昇に伴って喠液 $\mathrm{Na} / \mathrm{K}$ 比が低下すること，その機序 の一部が，アルドステロン分泌充進を介している可能性 があることを示唆している。

アルドステロン分泌は血清 $\mathrm{K}$ 値の上昇によって刺激さ れるといわれているのに，今回は血清 $\mathrm{K}$ 值と唾液アルド ステロン濃度との間には直接の相関はみられなかった。 このことから，血清K值が上昇した際の唾液 $\mathrm{Na} / \mathrm{K}$ 比の 低下には，アルドステロン以外の機序が関与している可 能性も考えられる。

\section{結論}

今回の結果は，1）維持透析患者の唾液 $\mathrm{K}$ 值が健常人 に比し有意な高値を示すこと，2）血清 $\mathrm{K}$ 值と唾液 $\mathrm{Na}$ / $\mathrm{K}$ 比が有意な負の相関を示すこと，3）血清 $\mathrm{K}$ 值上昇時 に唾液 $\mathrm{Na} / \mathrm{K}$ 比が低下する機序の少なくとも一部は血 漿アルドステロン值の上昇によること，などを示した。 これらの事実は，唾液 $\mathrm{Na} / \mathrm{K}$ 比が $\mathrm{K}$ 腎外調節の指標と して有効であることを示唆するものである。また今回の 結果は, 維持透析患者では腎外 $\mathrm{K}$ 排泄が高 $\mathrm{K}$ 血症の防止 に一役を担っていることを推定させるものである。しか し，このような腎外性 $\mathrm{K}$ 排泄機序が㗢いているにもかか わらず依然として高K血症を示す患者は多く，食事中の K制限や十分な透析によるKの除去が重要である.

本論文の要旨は, 第 36 回日本透析療法学会 (神戸) で発表 した。

\section{文献}

1）日本透析療法学会編：わが国の慢性透析療法の現 況. p 22, 1991

2) Hayes CP Jr, McLeod MI, Robinson R : An extrarenal mechanism for the maintenance of potassium balance in severe chronic renal failure. Trans Assoc Am Physicians 80 : 207-216, 1967

3) Martin RS, Panese S, Virginillo M, Gimenez M, Litardo M, Arrizurieta E, Hayslett JP : Increased secretion of potassium in the rectum of humans with chronic renal failure. Am J Kidney Dis 8: 105-110, 1986

4) Edmonds CJ, Godfrey RC : Measurement of electrical potentials of the human rectum and pelvic colon in normal and aldosterone-treated patients. Gut 11 : 330-337, 1970

5) Hayslett JP, Binder JH : Mechanisms of potassium adaptation. Am J Physiol 243 : F103-112, 1985

6) Schneyer LH, Young JA, Schneyer CA : Salivary secretion of electrolytes. Physiological reviews. $52: 720-777,1972$

7) Lauler DP, Hickler RB, Thorn GW : The salivary sodium-potassium ratio. N Engl J Med 29: 1136 $-1137,1962$

8) Shasha SM, Ben Aryeh H, Angel A, Gutman D : Salivary content in hemodialysed patients. J Oral Med 38:67-70, 1983

9) Burgen AS : The secretion of potassium in saliva. J Physiol 132 : 20-39, 1956

10) Gregerson MI, Ingalls EN : The influence of rate of secretion on the concentrations of potassium and sodium in dog's submaxillary saliva. Am J Physiol 98 : 441-446, 1931

11) Holmes JH, Crandall JI, Dwyer WC, Short WF : The relation of salivary flow to the state of hydration in patients with uremia and renal failure. Trans Am Soc Artificial Internal Organs 6 : 152-162, 1960

12) Few JD, Wallis JW, James VHT : The relationship between salivary aldosterone and plasma free aldosterone concentrations. Clin Endocrinol 24 : 119-126, 1986 